Beyond Philology No. 17/1, 2020

ISSN 1732-1220, eISSN 2451-1498

https://doi.org/10.26881/bp.2020.1.02

\title{
English as a lingua franca: Attitudes of Polish interpreting students
}

\author{
ALEKSANDRA SZYMAŃSKA-TWOREK \\ JOANNA SYCZ-OPOŃ
}

Received 23.06.2020, accepted 1.10.2020.

\begin{abstract}
Recent decades have witnessed the growing presence of English as a lingua franca (ELF) in international communication, which has emerged as one of the major factors influencing the interpreting profession. What follows is the debate concerning presence of ELF in interpreter training. However, before any curricula modifications are introduced, what needs to be taken into consideration is the perspective of interpreting students - their expectations and preferences concerning the variety of English they want to work with during their studies.

The present study is an attempt to investigate attitudes displayed by English philology students enrolled in translation and interpreting programmes towards native and non-native English. The research tool was a questionnaire. The results suggest that the students might not necessarily welcome frequent exposure to ELF at the cost of Standard British or Standard American English during practical classes, including interpreting. However, it is hypothesized that the respondents' conservative attitude is not the result of a thorough understanding of ELF, but rather the reflection of insufficient knowledge and uncritical embrace of the stereotypical mass-culture narration that tends to romanticize certain varieties of English while dismissing others.
\end{abstract}




\title{
Keywords
}

interpreter training, English as a lingua franca, non-standard English, language attitudes

\section{Angielski jako lingua franca: Postawy polskich studentów-tłumaczy}

\begin{abstract}
Abstrakt
W związku $\mathrm{z}$ rozpowszechnieniem języka angielskiego jako języka komunikacji międzynarodowej (English as a lingua franca, w skrócie $E L F)$ coraz częściej w dyskusji na temat kształcenia na kierunkach tłumaczeniowych, pojawia się postulat szerszej obecności ELF w programie nauczania, w celu lepszego przygotowania studentów na kontakt $z$ nienatywnymi odmianami języka angielskiego $w$ ich przyszłej pracy zawodowej. W debacie tej jednak rzadko brana jest pod uwage perspektywa samych studentów tłumaczy.

Niniejsze badanie ankietowe ma na celu ukazanie postaw, jakie studenci grup tłumaczeniowych na kierunku filologia angielska przybieraja wobec natywnych (UK, US) oraz nienatywnej odmiany języka angielskiego (PL), oraz wobec swojego użycia tego języka. Wyniki ukazuja stereotypowe i konserwatywne podejście studentów do badanych odmian jezzyka, $z$ silnym przywiazaniem do odmiany brytyjskiej uznawanej w wielu aspektach za lepsza. Wyniki sugeruja, iż studenci moga nie być gotowi na przyjęcie postulatów nowego paradygmatu nauczania, zakładajacego równomierna ekspozycje na wiele różnych odmian języka angielskiego, w tym nienatywnych.
\end{abstract}

\section{Słowa kluczowe}

kształcenie tłumaczy języka angielskiego, angielski jako lingua franca, angielski nienatywny, postawy wobec języka 


\section{The spread of English as a lingua franca (ELF)}

When discussing the status of English in a globalized world today, Seidlhofer (2011: 7) reflects: "for the first time in history, a language has reached truly global dimensions, across continents, domains, and social strata". We have come to the point when native speakers of English ( $\left.\mathrm{NSE}^{1}\right)$ are significantly outnumbered by non-native speakers of English (NNSE): there are now five NNSE for each NSE (David Crystal at a lecture at Bangor University in 2012, cited in Albl-Mikasa 2014: 25). Today English is the lingua franca of business, tourism, politics, scientific research and many other domains that require professional international communication (Rogerson-Revell 2007). A frequently quoted definition of English as a lingua franca (ELF) is the one proposed by Seidlhofer (2011: 7), who describes ELF as "any use of English among speakers of different first languages for whom English is the communicative medium of choice, and often the only option".

The unprecedented spread of English as a vehicular language of international and intercultural communication has prompted scholars to raise questions about the validity of existing pedagogical models that base heavily on what Galloway (2013: 786) terms as "native English speaker episteme". English language teaching has traditionally taken a native speaker as a default point of reference (Jenkins 1998, Spichtinger 2001, McKay 2003). However, as claimed by many (Cook 1999, Jenkins 2000, 2007, Matsuda 2003, Seidlhofer 2011), the traditional native speaker-based models have become of limited value in international communication because they do not prepare students for the future situational contexts of English

1 The term "native speaker of English" (NSE) is used in the present paper to refer to Inner Circle uses and users of English, and "non-native speaker of English" (NNSE) as an umbrella term for Outer and Expanding Circle English. Although we are aware that defining linguistic nativity is problematic (Cook 1999, Davies 1991), we have decided to follow this dichotomy because it is the terminology which our respondents are most familiar with. 
use. Scholars such as Jenkins $(2000,2007)$ and Seidlhofer (2011) advocate that, rather than focusing on mechanical mimicry of Received Pronunciation or General American accents, a present-day language classroom should equip students with the tools enabling them to communicate in a wide range of contexts across the three Kachruvian circles. ${ }^{2}$ As argued by Friedrich (2012: 50), "[i]f the only constant in lingua franca situations is diversity, then we should anchor our practices in that assumption and educate students to encounter such diversity with respect, curiosity and wisdom".

\section{ELF in the context of interpreting and interpreter training}

The analysis of the implications that the spread of ELF has had on the field of translation and interpreting is a very recent object of study (Albl-Mikasa 2014: 19). While earlier research concentrated exclusively on the ways in which the interpreters' performance was impacted by a foreign accent, only a few studies explored the wider repercussions that ELF had on the interpreting activity (Albl-Mikasa, Guggisberg and Talirz 2017: 267). However, as the emergence of ELF has been identified as "one of the most significant issues for interpreting today" (Gentile and Albl-Mikasa 2017: 53), it seems that research on the

2 In order to refer to different varieties of English, we employ Kachru's well-known concentric circles model (1985), which describes the role and use of English around the world by classifying countries into three broad categories: Inner Circle, Outer Circle and Expanding Circle. The Inner Circle includes countries where English is the native language or mother tongue, e.g. the United Kingdom or Australia. Outer Circle countries are former British or American colonies where English serves a number of institutionalized roles and often functions as either an official or a second language, e.g. India, Singapore, Malaysia or Nigeria. In Expanding Circle countries (e.g. Poland, France, Thailand or China), English does not have an official status and is learned as a foreign language. Its representations, such as Polish English or French English, are not classified as varieties of English. However, some scholars refer to them as sub-varieties (e.g. Jenkins 2005: 64) because of the increasing number of people who use them in multiple domains. 
topic in question has gathered momentum. Albl-Mikasa, one of the leading researchers in the field of interpreting in the context of ELF, has announced the emergence of a new subdiscipline, namely ITELF, which is an acronym standing for "interpreting, translation and English as a lingua franca" (AlblMikasa 2014, 2017).

It seems that ELF is to remain a constant element of the meetings and events that require interpreters' services. It should come as no surprise, then, that the considerations of the ELF-oriented pedagogy have recently entered the field of interpreter training. As interpreter students are still predominantly trained for contexts in which native speakers communicate with other native speakers of different languages (AlblMikasa 2014: 33, Albl-Mikasa, Bartels, Mohler and Wick 2017: 216), more and more studies have called for the necessity to reconsider what interpreter training courses should look like in order to prepare interpreters-to-be for the ELF-saturated reality (e.g. Jones 2014, Chang and Wu 2014, Albl-Mikasa 2013, 2014). As put by Albl-Mikasa (2013: 12): "[i]n light of the growing number of nonnative English speakers at conferences and the implications reported by professional interpreters, there can be little doubt that interpreter training must undergo changes with a view to integrating an ELF orientation".

Albl-Mikasa (2013) provides a detailed proposal of modifications that could be introduced to interpreter training courses in order to make them more ELF-oriented. These include, among others, alterations to different dimensions of the interpreters' processing: comprehension (as interpreters must be able to understand NNES), production (interpreters should reconsider their production competence), as well as awareness raising practices (interpreter students need to be informed about ELF-related developments and their implications for the interpreting activity). As far as comprehension is concerned, Albl-Mikasa (2013: 7) recommends that interpreter students need to be exposed to a great variety of accents because "[t]he more they get used to the foreignness, the less such expres- 
sions will appear odd and new", or, as aptly put by one of the interpreters in Albl-Mikasa's study: "[t]he 24th Chinese speaker may still be difficult to understand, but much less so than the first one" (Albl-Mikasa 2013: 7). Taking production into consideration, Albl-Mikasa (2013: 10) points out that interpreter students should be sensitized to be ready not to use sophisticated idiomatic expressions, when, for example, working for NNES listeners. As put by one of the respondents in Albl-Mikasa's study: "[w]hat is the use of throwing in expressions like "I would concur with the chairman" or "that's a sticky wicket," when no one understands them?" (AlblMikasa 2013: 7). Other studies offering recommendations and suggestions for an ELF orientation in interpreter training include Albl-Mikasa, Bartels, Mohler and Wick (2017) and AlblMikasa (2014).

\section{Language attitudes of university students}

In this discussion between academics and professionals on the need for an ELF pedagogy in interpreter training, one should not forget about the voice of university students, whose expectations and preferences concerning the kind of English they want to work with during their studies should be taken into consideration. Numerous language attitude studies have explored the perceptions of ELF displayed by university students majoring in English (e.g. Erling and Bartlett 2006, Margić and Širola 2009, Ozturk, Cecen and Altinmakas 2009, Wach 2011, Luo 2018), although, as far as we know, the vast majority of these studies have been conducted among students enrolled in teacher education programmes. Data supplied in these studies generally point to a traditional, native-speaker orientation displayed by the majority of university students, although considerable differences are visible between particular studies. What is interesting in the context of the present paper, Margic and Sirola (2009) as well as Wach (2011) report that students' attitudes are, to a large extent, influenced by the content of uni- 
versity courses they are enrolled in. For example, in the study by Wach (2011), students who received more intensive training in pronunciation and who were highly expected to achieve native-like standards, displayed less balanced attitudes towards native-speaker versus ELF pronunciation norms that a group of students whose pronunciation training was shorter in length. In the case of the latter group, although a preference for native-speaker pronunciation models still prevailed, the students were willing to acknowledge the value of ELF pronunciation norms in learning and teaching English, including their own language development.

As already pointed out, it seems to us that the vast majority of university students majoring in English whose attitudes were investigated in ELF-related attitudinal studies are students enrolled in teacher education programmes. The attitudes of interpreter students seem to be under-researched and hence the idea for the study presented in this paper. This research is an attempt to investigate attitudes displayed by the students enrolled in translation/interpreting programmes of English philology studies towards native and non-native English. The research questions are as follows: Are interpreter students aware of the phenomenon of English as a lingua franca? Do they envisage exposure to different varieties and sub-varieties (see footnote no. 2) of English in their future professional life? How do they perceive themselves and their teachers as NNES? In general, our study aims to explore: do interpreter students have sufficient knowledge and understanding of the place and role of English in the modern world to appreciate modifications to interpreting training advocated by the proponents of ELF?

\section{Methodology}

\subsection{Participants}

The study involved participation of 131 respondents from two higher education institutions in Poland: the University of Sile- 
sia in Katowice $(n=91)$ and the University of Warsaw $(n=40)$. The participants were English philology students enrolled in translation and interpreting programmes, at both undergraduate and graduate level, who had completed at least 30 hours, i.e. one course of interpreting, at the moment of completing the questionnaire. The students from the University of Silesia (also referred to as US throughout the paper) had completed, on average, 150 hours of translation and 90 hours of interpreting classes at the moment of filling out the questionnaire. The students from the University of Warsaw (also referred to as UW hereafter) had completed, on average, 120 hours of translation and 60 hours of interpreting classes.

\subsection{Research site}

The study took place in Poland - an Expanding Circle country (see footnote no. 2). Typically, English philology studies in Poland offer a number of different specializations, including, among others, translation and interpreting programmes, teaching programmes and business programmes. Apart from courses in translation and interpreting, translation and interpreting programmes typically comprise courses in, among others, practical English skills (e.g. reading and listening comprehension, grammar, phonetics), linguistics and culture and literature of English-speaking countries. What needs to be stressed is that English philology students enrolled in translation and interpreting programmes are trained in both - translation and interpreting - since the aim of the programme is to prepare them to perform both of these roles on the market. During practical English classes, including phonetics, students typically practise one of the two varieties: Standard British or Standard American. 


\subsection{Questionnaire design}

The tool of investigation in this study was a questionnaire modelled on the collection tools applied in the previous investigation by one of the authors of the present paper (Szymańska-Tworek 2016), i.e. a questionnaire consisting of 56 questions, 15 of which were re-used in the present study ${ }^{3}$ (see Appendix). In order to qualify respondents for the study, the 15-item questionnaire was supplemented with two additional questions enquiring about the number of hours of interpreting and translation classes completed by the respondents at the moment of filling in the questionnaire. We decided not to ask the students directly about their attitude towards ELF, believing the answers would not show the true picture, but rather investigate their attitudes through a series of indirect questions. The questionnaire was divided into three sections consisting of multiple-choice and open questions:

1. The first part (questions 1 to 5) concerned students' knowledge of the concept of ELF as well as their awareness of the varietal diversity of the English-using world. The respondents were asked about the concept "English as a lingua franca" and the number of English (sub)varieties they can enumerate. In order to verify their declared knowledge, they were asked to provide a definition of ELF and to write down the (sub)varieties of English they know that exist. The respondents were also asked about whether they predict to use English more often with NSE, NNSE or equally often with both NSE and NNSE.

2. The second part of the questionnaire (questions 6 to 8) aimed to reveal the students' attitudes towards Inner Circle English (British and American) as well as Polish English, i.e. a subvariety of English spoken by the majority of the respondents themselves, their fellow students and teachers. The respond-

3 The remaining questions were not included. The original study investigated trainee teachers, thus a number of questions enquired specifically about the context of teaching practice and were unsuited for the interpreting context. 
ents were asked to write down adjectives that, in their opinion, best describe these three varieties of English.

3. In the third section (questions 9 to 15), we wanted to examine the aspirations of our respondents concerning their own English accent and their inclinations towards Standard English. We asked whether they prioritize native-like accent in their own use of English, i.e. whether they speak English with a non-native accent and, if so, if they perceive it as a problem; how important it is for them to sound like an NSE and to what extent, in their opinion, university teachers should focus on native-speaker pronunciation during classes.

\subsection{Data analysis}

When presenting the results of the study, the quantitative data are represented in the form of percentages for two groups separately (US and UW). The open-ended questions $(2,4,6-8,11$, 13 and 15) were analyzed qualitatively. The responses were first coded using words and descriptive phrases and then categorized into themes. When presenting responses to openended questions, no differentiation is made between US and UW, because the responses provided by both groups are very similar. Also, due to space limitations, only the most frequent responses are presented. The presentation of the results is supported by quotations from the questionnaire, cited verbatim. The quotations were selected due to their representativeness. It has been our intention that the quotations included in the article represent strands of opinion rather than individual voices. 


\section{Study results}

Questions 1 and 2: Are you familiar with the concept "English as a lingua franca"? If yes, please give a definition of "English as a lingua franca".

When it comes to the familiarity with the concept of ELF, $69.2 \%$ of the US respondents and $82.5 \%$ of the UW respondents stated that they were acquainted with this phenomenon, with the remaining $30.8 \%$ US and $17.5 \%$ UW admitting unfamiliarity. All of the definitions provided by the students were correct, but fairly basic. The typical definitions were as follows:

(1) English as language spoken around the world in many different fields and understandable for most people

(2) English as a global language

(3) this is English used as an international language

\section{Questions 3 and 4: How many (sub)varieties of English do you know that exist? Please, enumerate them.}

The respondents produced a heterogeneous set of answers when asked about their knowledge of the (sub)varieties of English, with the majority declaring knowledge of six or more.

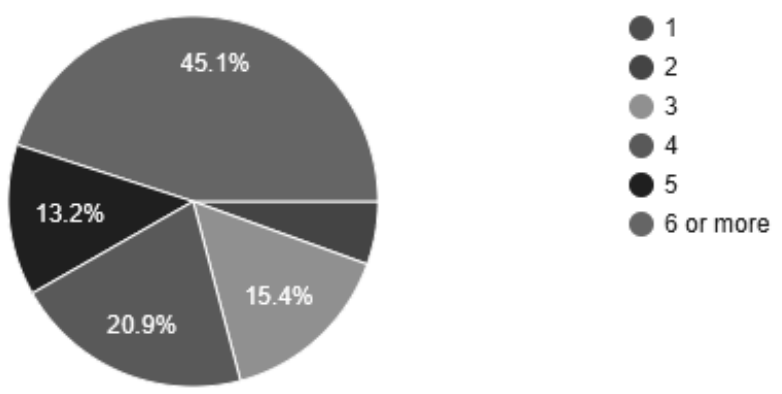

Figure 1

Number of English (sub)varieties the US respondents said they were familiar with 


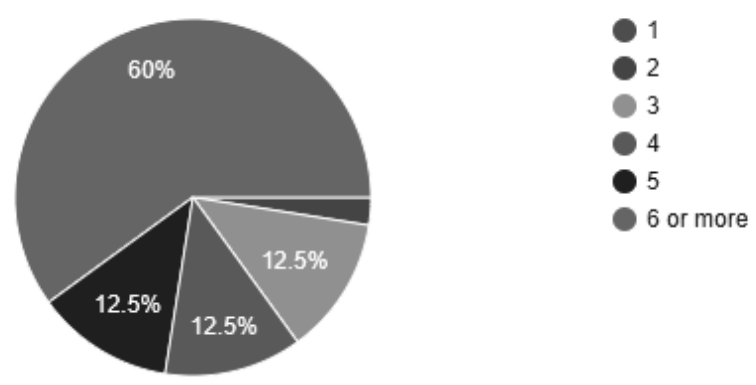

Figure 2

Number of English (sub)varieties the UW respondents said they were familiar with

The US respondents who stated that there were only two (sub)varieties of English (5.5\%) enumerated British and American. The informants who indicated that there were three (15.4\%) enumerated British and American, as well as one of the following: Australian, Canadian, Irish or South African. The subjects declaring the knowledge of four (20.9\%) or five (13.2\%) (sub)varieties mentioned: New Zealand, Scottish, Welsh, African American Vernacular English, Appalachian English, Cajun, Received Pronunciation, Scouse and Cockney. The respondents who indicated that they knew of six or more can be further divided into three clusters. The first one comprises students who gave examples of only Inner Circle English, the second includes the respondents who enumerated (sub)varieties from both Inner and Outer Circle countries (Malaysian English, Singaporean English, Jamaican English, Caribbean English, Asian English, "Hinglish"). The last cluster, consisting of only three respondents, provided examples from across the three Kachruvian circles, including Expanding Circle (Chinese English, Thai English and Mexican English).

The responses provided by the UW students are fairly similar. The students who stated that there were two, three, four and five (sub)varieties of English enumerated exclusively Inner Circle English. The UW respondents who enumerated six or more can be divided into two clusters. The students in the first 
cluster gave examples of only Inner Circle English, while the respondents in the second cluster provided examples from both Inner and Outer Circle. No examples of Expanding Circle English were provided.

Question 5: I think I will probably use English more often with...

As regards the students' predictions concerning their use of English, the majority (40.7\% US and 52.5\% UW) declared they expected to use English most frequently with NNSE. Ranked second among the US students $(24.2 \%)$ was the prediction to communicate most often with NSE. The second most numerous response among the UW respondents $(27.5 \%)$ was the prediction to communicate equally often with NSE and NNSE.

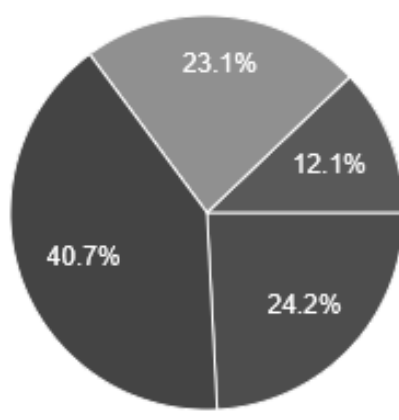

native speakers

non-native speakers

equally often with native and nonnative speakers

i don't know

\section{Figure 3}

US respondents' predictions concerning their use of English 


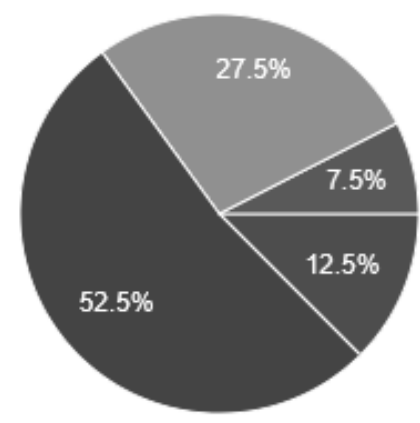

native speakers

non-native speakers

equally often with native and nonnative speakers

i don't know

Figure 4

UW respondents' predictions concerning their use of English

Questions 6, 7 and 8: What adjectives would you use to describe British English? American English? English spoken by Polish people?

In the following series of questions, the respondents were asked to provide adjectives to describe two native varieties of English: British and American, and one non-native subvariety: English spoken by Polish people (so-called Polish English). The results are shown in Tables 1-6. All comments were divided into three categories: positive, negative and neutral, based on our judgment (ambiguous cases were consulted with other academic teachers until consensus was reached). The numbers in parentheses indicate the number of respondents who wrote down a particular word or phrase. Even though some of the words may be susceptible to different interpretations (e.g., "rough", "flat", "rigid" or "difficult" may be considered a neutral feature or criticism, depending on respondents' intentions), the general attitudes towards UK, US and Polish English are clearly visible. Regarding British English, the descriptors provided by the respondents were mainly positive: 59\% (US) and 67.7\% (UW). As regards American English, the majority $(62.3 \%$ US and $68 \% \mathrm{UW})$ of the descriptors can be classified as neutral. The respondents associate British Eng- 
lish mostly with sophistication, elegance, upper class, beauty, melodic sound, education, eloquence and formality, while American English is perceived as easy, common, informal, practical, friendly and casual.

Quite in contrast, when asked to describe Polish English the respondents provided mostly negative descriptors (55.2\% US and 60.8\% UW), calling it "harsh", "incorrect", "poor" or even "broken" or "nauseating". The respondents seem to associate Polish English - that is a sub-variety of English they hear most often in their fellow students and teachers and one they are likely to speak themselves - with simplicity, incorrectness, poor pronunciation, strong accent and sloppiness.

Table 1

US respondents' description of British English

\begin{tabular}{|c|c|c|}
\hline $\begin{array}{c}\text { Positive comments } \\
118=59 \%\end{array}$ & $\begin{array}{c}\text { Neutral comments } \\
61=30.5 \%\end{array}$ & $\begin{array}{c}\text { Negative comments } \\
21=10.5 \%\end{array}$ \\
\hline $\begin{array}{l}\text { sophisticated (33), } \\
\text { posh (13), elegant } \\
\text { (11), melodic (6), } \\
\text { beautiful (5), intelli- } \\
\text { gent (4), smooth (4), } \\
\text { smart (3), attractive } \\
\text { (2), gentle (2), inter- } \\
\text { esting (2), nice (2), } \\
\text { clear (2), accurate, } \\
\text { amazing, awesome, } \\
\text { better, classy, deli- } \\
\text { cate, dignified, edu- } \\
\text { cational, elevated, } \\
\text { eloquent, fanciful, } \\
\text { fancy, flowerish, } \\
\text { magnificent, more } \\
\text { posh, nice accent, } \\
\text { noble, polite, prefer- } \\
\text { able, professional, } \\
\text { refined, sexy, so- }\end{array}$ & $\begin{array}{l}\text { soft (4), classic (3), } \\
\text { royal (3), difficult (3), } \\
\text { official (3), specific } \\
\text { (3), academic (2), } \\
\text { complex (2), compli- } \\
\text { cated (2), formal (2), } \\
\text { more complicated } \\
\text { (2), non-rhotic (2), } \\
\text { strong (2), tough (2), } \\
\text { traditional (2), artis- } \\
\text { tic, basic, common, } \\
\text { deep, difficult to } \\
\text { pronounce, diverse, } \\
\text { easy to learn, eco- } \\
\text { nomical, elaborate, } \\
\text { fluent, free-flowing, } \\
\text { Germanic, girly, } \\
\text { high, language of } \\
\text { the royalty, long, } \\
\text { lordly, more difficult }\end{array}$ & $\begin{array}{l}\text { difficult to under- } \\
\text { stand (3), sometimes } \\
\text { incomprehensible } \\
\text { (2), artificial (2), } \\
\text { pompous (2), } \\
\text { cheeky, decadent, } \\
\text { exaggerated, hard to } \\
\text { grasp, harsh, high- } \\
\text { strung, impertinent, } \\
\text { irritating, odd, out- } \\
\text { rageous, sharp, un- } \\
\text { clear }\end{array}$ \\
\hline
\end{tabular}


phisticated in pronunciation, pleasant, poetic, sublime, subtle, sweet, upper-class

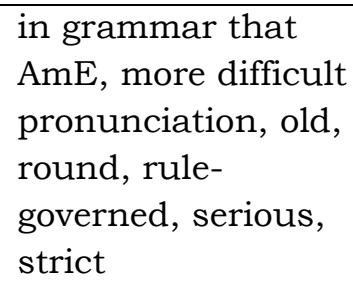

Table 2

UW respondents' description of British English

\begin{tabular}{|l|l|l|}
\hline \multicolumn{1}{|c|}{$\begin{array}{c}\text { Positive comments } \\
44=67.7 \%\end{array}$} & \multicolumn{1}{|c|}{$\begin{array}{c}\text { Neutral comments } \\
17=26.1 \%\end{array}$} & $\begin{array}{c}\text { Negative comments } \\
4=6.2 \%\end{array}$ \\
\hline $\begin{array}{l}\text { sophisticated (10), } \\
\text { posh (6), elegant (5), } \\
\text { attractive (2), distin- } \\
\text { guished (2), fancy } \\
\text { (2), melodious (2), } \\
\text { stylish (2), beautiful, } \\
\text { bewitching, classy, } \\
\text { complex, complicat- } \\
\text { excellent, fascinat- } \\
\text { ing, magnificent, formal, } \\
\text { French-influenced, } \\
\text { light, official, royal, } \\
\text { lodic, nice to ear, } \\
\text { sopulent, }\end{array}$ & $\begin{array}{l}\text { affected, crisp- } \\
\text { sounding, hard to } \\
\text { understand, }\end{array}$ & \\
ically-confusing & \\
posh-sounding, & & \\
perior, well-regarded & & \\
\hline
\end{tabular}

Table 3

US respondents' description of American English

\begin{tabular}{|l|l|l|}
\hline \multicolumn{1}{|c|}{\begin{tabular}{c} 
Positive comments \\
\multicolumn{1}{|c|}{$43=25.7 \%$}
\end{tabular}} & \multicolumn{1}{|c|}{$\begin{array}{c}\text { Neutral comments } \\
104=62.3 \%\end{array}$} & \multicolumn{1}{c|}{$\begin{array}{c}\text { Negative comments } \\
20=12 \%\end{array}$} \\
\hline clear (7), easy to un- & simple (13), easy & simplified (4), churl- \\
derstand (4), friendly & $(10)$, common (6), & ish, direct as a bul- \\
(3), nice (3), colour- & lazy (5), casual (4), & let to the head, ex- \\
ful (2), more natural & popular (4), rhotic & aggerated, harsh, \\
(2), professional (2), & (4), easier (3), every- & horrible, irritating, \\
confident, easier to & day language (3), & less interesting, \\
grasp, easier to un- & laid-back (3), practi- & overextended, shal- \\
\hline
\end{tabular}




\begin{tabular}{|c|c|c|}
\hline $\begin{array}{l}\text { derstand, easy- } \\
\text { going, efficient, ele- } \\
\text { gant, happy, inter- } \\
\text { esting, melodic, } \\
\text { more friendly, natu- } \\
\text { ral, nice-sounding, } \\
\text { pure, smart, spon- } \\
\text { taneous, under- } \\
\text { standable, very } \\
\text { friendly }\end{array}$ & $\begin{array}{l}\text { cal (3), rough (3), } \\
\text { colloquial (2), fluent } \\
\text { (2), plain (2), slangy } \\
\text { (2), accessible, busi- } \\
\text { ness-like, clipped, } \\
\text { concrete, direct, dy- } \\
\text { namic, down to } \\
\text { earth, easier than } \\
\text { British, easier to } \\
\text { pronounce, easy } \\
\text { (taking into account } \\
\text { grammar), easy to } \\
\text { pronounce, explicit, } \\
\text { expressive, fast, } \\
\text { firm, fluid, free, } \\
\text { heavy, informal, in- } \\
\text { formal-sounding } \\
\text { (even in formal con- } \\
\text { texts), light, more } \\
\text { common, nasal, } \\
\text { open, ordinary, } \\
\text { popular, prevailing, } \\
\text { quick, relaxed, } \\
\text { shortened, simpler, } \\
\text { soft, standard, } \\
\text { straightforward, } \\
\text { tough }\end{array}$ & $\begin{array}{l}\text { low, sloppy, } \\
\text { squeaky, too re- } \\
\text { laxed, unbearably } \\
\text { nasal, unclear, unti- } \\
\text { dy, unrefined }\end{array}$ \\
\hline
\end{tabular}

Table 4

UW respondents' description of American English

\begin{tabular}{|l|l|l|}
\hline \multicolumn{1}{|c|}{$\begin{array}{c}\text { Positive comments } \\
9=18 \%\end{array}$} & \multicolumn{1}{c|}{$\begin{array}{c}\text { Neutral comments } \\
34=68 \%\end{array}$} & \multicolumn{1}{c|}{$\begin{array}{c}\text { Negative comments } \\
7=14 \%\end{array}$} \\
\hline $\begin{array}{l}\text { relaxed (3), clear, } \\
\text { easy to understand, } \\
\text { friendly, laid-back, } \\
\text { trendy, understand- } \\
\text { able }\end{array}$ & $\begin{array}{l}\text { common (6), ordinary } \\
\text { (3), easier to pro- } \\
\text { nounce (2), easy (2), } \\
\text { fast (2), neutral (2), } \\
\text { popular (2), casual, }\end{array}$ & $\begin{array}{l}\text { artificial, boring, } \\
\text { poor, simplified, } \\
\text { sloppy, terrible, un- } \\
\text { pleasant }\end{array}$ \\
\hline
\end{tabular}




\begin{tabular}{|l|l|}
\hline down-to-earth, flat, \\
informal, modern, \\
tough, more popular, \\
negligent, old- \\
fashioned, prescrip- \\
tive, prevailing, \\
rough, soft, thick, \\
unofficial
\end{tabular} \mid

Table 5

US respondents' description of English spoken by native speakers of Polish

\begin{tabular}{|c|c|c|}
\hline $\begin{array}{c}\text { Positive comments } \\
9=6.2 \%\end{array}$ & $\begin{array}{l}\text { Neutral comments } \\
56=38.6 \%\end{array}$ & $\begin{array}{c}\text { Negative comments } \\
80=55.2 \%\end{array}$ \\
\hline $\begin{array}{l}\text { fluent (3), clear, } \\
\text { communicative, } \\
\text { comprehensible, } \\
\text { good, grammatically } \\
\text { correct, sometimes } \\
\text { really good }\end{array}$ & $\begin{array}{l}\text { funny (9), hard (7), } \\
\text { simple (6), careful } \\
\text { (3), flat (2), square } \\
\text { (2), tough (2), basic, } \\
\text { cautious, complicat- } \\
\text { ed, different pro- } \\
\text { nunciation, direct, } \\
\text { diverse, easy, } \\
\text { grammar-focused, } \\
\text { hard to specify, hiss- } \\
\text { ing, influenced, } \\
\text { monochromatic, } \\
\text { Polglish, Polish ac- } \\
\text { cent, Ponglish, prac- } \\
\text { tical, recognizable, } \\
\text { rigid, Russian-like, } \\
\text { shy, sharp, Slavic } \\
\text { accent, specific, } \\
\text { straight, varied }\end{array}$ & $\begin{array}{l}\text { harsh (5), rough (5), } \\
\text { incorrect (4), awk- } \\
\text { ward (2), bad (2), } \\
\text { clumsy (2), heavily } \\
\text { accented (2), incom- } \\
\text { plete (2), misspelled } \\
\text { (2), not fluent (2), } \\
\text { primitive (2), simpli- } \\
\text { fied (2), stiff (2), } \\
\text { strange (2), unnatu- } \\
\text { ral (2), wrong (2), } \\
\text { accentless, artificial, } \\
\text { poor, bad pronunci- } \\
\text { ation, broken, clum- } \\
\text { sy, full of bad ac- } \\
\text { cent, grammar and } \\
\text { word-lacking, help- } \\
\text { less, imperfect, in- } \\
\text { coherent, incompre- } \\
\text { hensible, incorrect, } \\
\text { inelegant, it doesn't } \\
\text { sound like English, } \\
\text { low knowledge of vo- } \\
\text { cabulary, mechani- }\end{array}$ \\
\hline
\end{tabular}




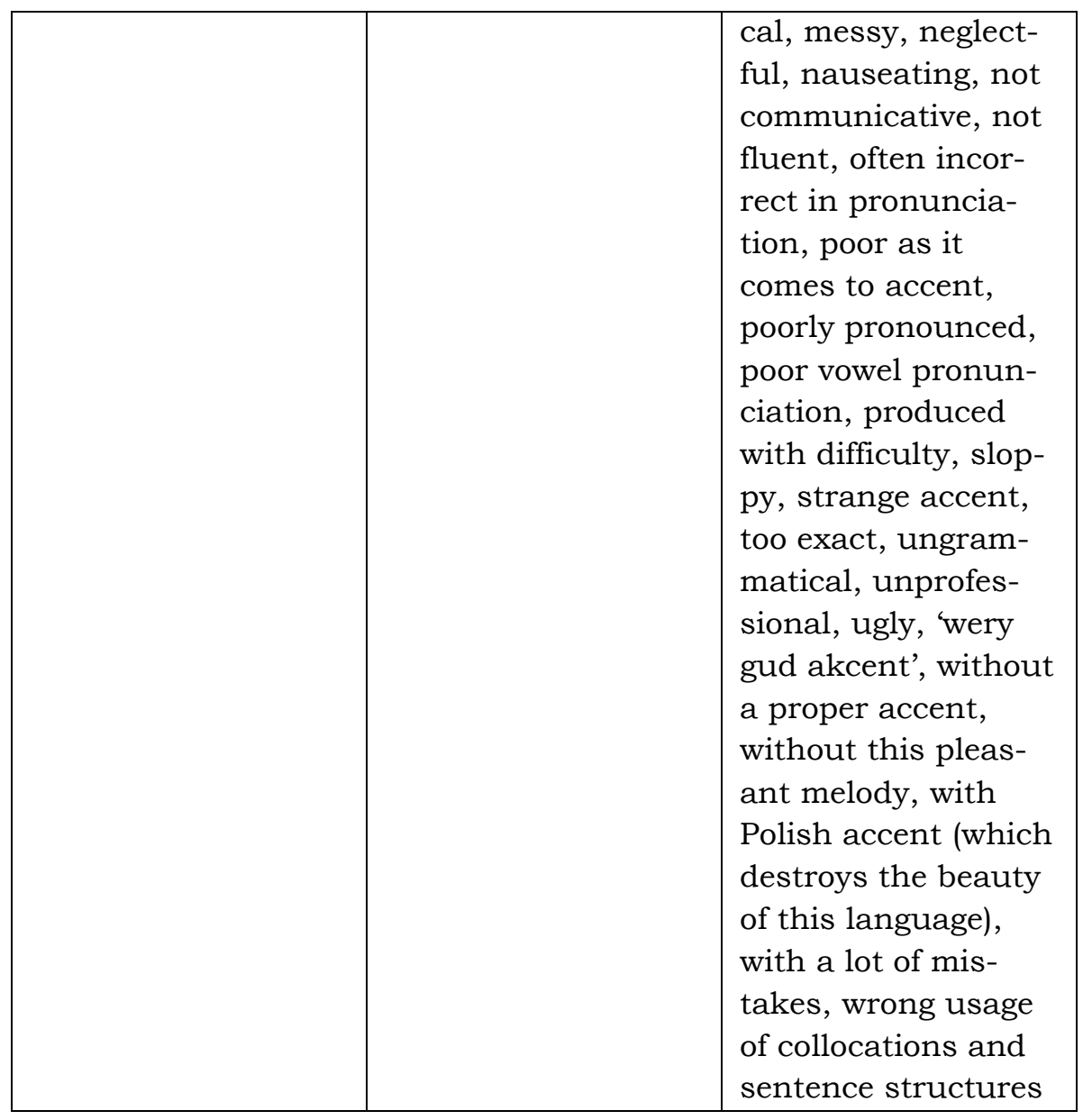

Table 6

UW respondents' description of English spoken by native speakers of Polish

\begin{tabular}{|l|l|l|}
\hline \multicolumn{1}{|c|}{$\begin{array}{c}\text { Positive comments } \\
12=23.5 \%\end{array}$} & \multicolumn{1}{c|}{$\begin{array}{c}\text { Neutral comments } \\
8=15.7 \%\end{array}$} & $\begin{array}{c}\text { Negative comments } \\
31=60.8 \%\end{array}$ \\
\hline $\begin{array}{l}\text { understandable (3), } \\
\text { correct (2), compre- } \\
\text { hensible, easy to un- } \\
\text { derstand, efficient, } \\
\text { fluent, good, gram- }\end{array}$ & $\begin{array}{l}\text { simple (2), formal (2), } \\
\text { funny (2), hard, flat }\end{array}$ & $\begin{array}{l}\text { imperfect (2), rough } \\
\text { (2), angular, appre- } \\
\text { hensive, artificial, } \\
\text { awkward, badly pro- } \\
\text { nounced, broken, }\end{array}$ \\
\hline
\end{tabular}




\begin{tabular}{|c|c|}
\hline $\begin{array}{l}\text { matically communi- } \\
\text { cative, natural }\end{array}$ & $\begin{array}{l}\text { clumsy, discordant, } \\
\text { embarrassing, harsh, } \\
\text { not confident, not } \\
\text { fluent, inaccurate, } \\
\text { incorrectly pro- } \\
\text { nounced, school- } \\
\text { learned, their accent } \\
\text { hurts my ears, pain- } \\
\text { ful, shaky, sloppy, } \\
\text { stilted, ugly, unat- } \\
\text { tractive, ungrammat- } \\
\text { ical, unnatural, un- } \\
\text { polished, weighty, } \\
\text { weird }\end{array}$ \\
\hline
\end{tabular}

Questions 9, 10 and 11: Do you speak English with a Polish/non-native accent? If you do, is it a problem for you? Why?

When asked if they speak English with an L1-influenced accent, $35.6 \%$ of the US subjects and $45 \%$ of the UW subjects answered affirmatively, while $32.2 \%$ of the US respondents and $35 \%$ of the UW respondents answered negatively. No definitive answer was provided by $32.2 \%$ of the US students and $20 \%$ of the UW students. 


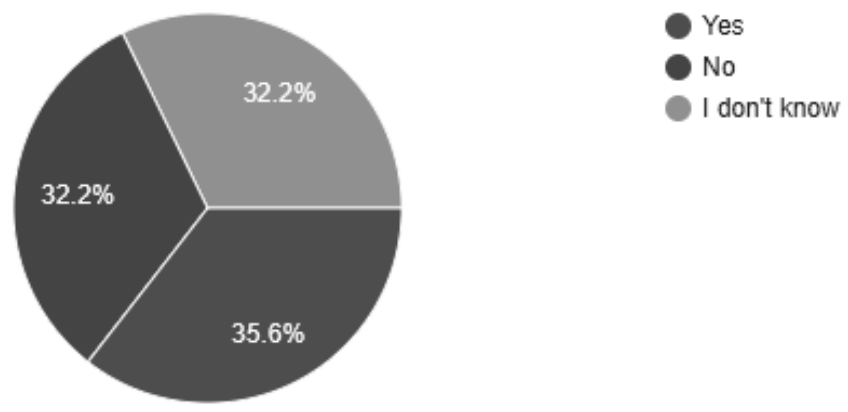

Figure 5

US respondents' evaluation of whether their English is L1-influenced

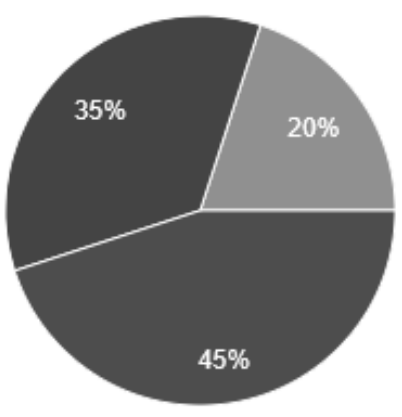
Yes
No
I don't know

\section{Figure 6}

UW respondents' evaluation of whether their English is L1-influenced

Of those who claim to speak L1-influenced English, $40 \%$ of the US group and $45.2 \%$ of the UW group consider it a problem, $38.8 \%$ of the US students and $38.7 \%$ of the UW students find it unproblematic, while $21.3 \%$ of the US respondents and $16.1 \%$ of the UW respondents have no opinion. 


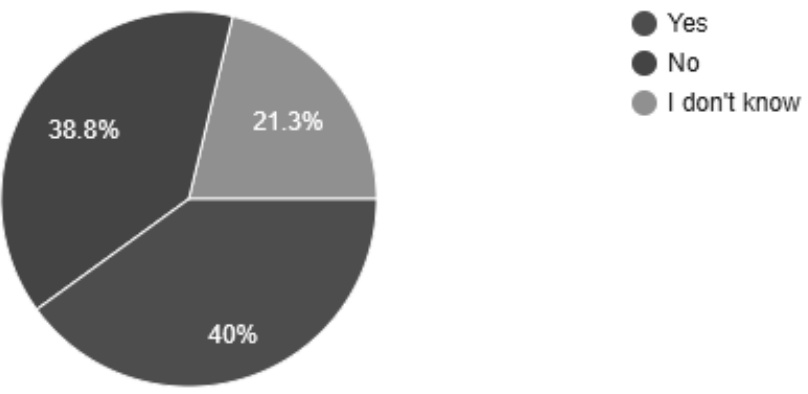

Figure 7

US respondents' evaluation of whether their L1-influenced English is a problem for them

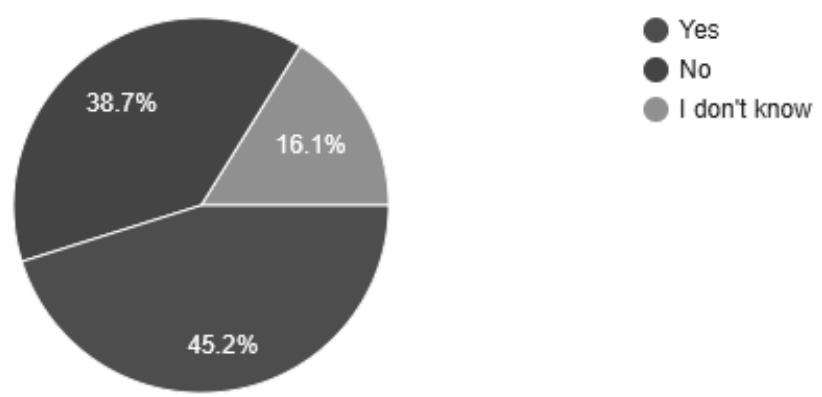

Figure 8

UW respondents' evaluation of whether their L1-influenced English is a problem for them

The respondents who are not satisfied with their Polishaccented English provide the following arguments:

- speaking English with a non-native accent sounds unprofessional or uncultured;

- English with a Polish accent sounds bad;

- philology students are expected to sound native;

- it is undesirable when people can guess nationality basing on one's accent.

(4) It might seem unprofessional for people I work with. 
(5) Yes, because I think the more a person sounds like a native speaker, the more educated they seem. Speaking poorly makes you seem uncultured, like you haven't been places or met people from other countries.

(6) Because I don't like the sound of Polish English, it sounds stupid.

(7) Because it is frowned upon not to speak ideal English while studying it.

The opinions of respondents who claim to accept their Polishaccented English cluster around two lines of reasoning:

- Polish-accented English does not affect one's communication skills;

- having an L1-influenced accent makes one's English sound original, interesting and unique.

(8) I don't have an aspiration to sound more British than British themselves, as long as I'm understood by both native and non-native speakers of English I think it's enough. The point of knowing any language is to communicate. Of course if one day I acquire certain accent (for instance by means of staying abroad) then I will be very happy about it, but it's not my priority.

(9) The friend of mine has come to the conclusion that it is "sweet" when a Polish person speaks English with a Polish accent, it sounds peculiar and original.

\section{Question 12 and 13: How important is it for you to sound like a native speaker of English? Why?}

Question 12 generated fairly homogeneous answers in both groups, as presented in Figures 9 and 10. A clear majority finds it very important (46.2\% US and 40\% UW) and important (35.2\% US and 35\% UW) to master native-like pronunciation. 


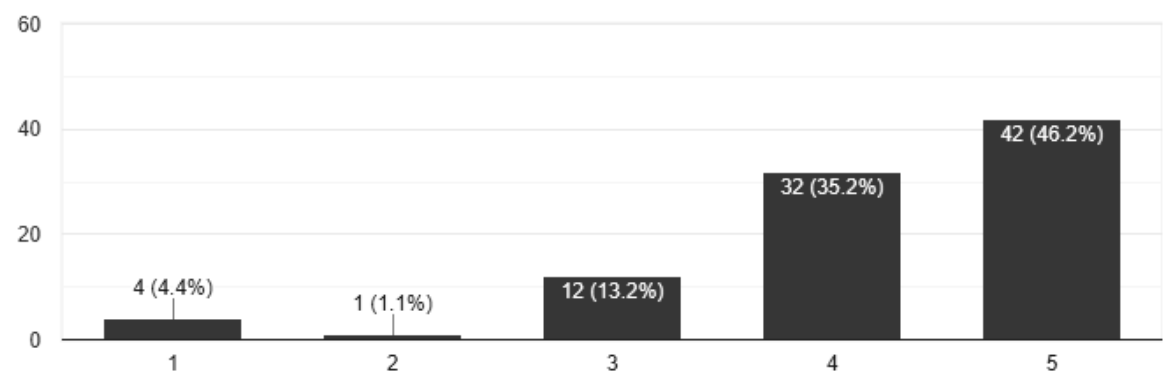

Figure 9

US respondents' desire to sound like a native speaker of English (5 - it is very important, 1 - not important at all)

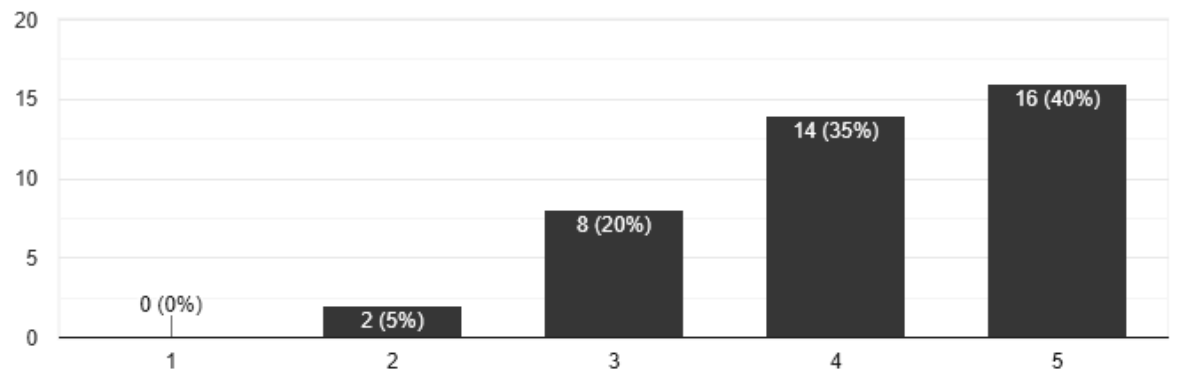

Figure 10

UW respondents' desire to sound like a native speaker of English

( 5 - it is very important, 1 - not important at all)

The following reasons were provided by respondents who state that acquiring a native-speaker accent is important for them:

- speaking English with a native accent sounds professional/speaking with a non-native accent sounds unprofessional;

- native-like accent is more intelligible for both NSE and NNSE;

- developing a native-like accent is part and parcel of learning a foreign language;

- having a native accent shows that one is competent in their use of English;

- speaking with a native accent makes one more competitive on the job market;

- sounding like an NSE is important in interpreters' job; 
- having a native accent makes people think that one is an NSE;

- it is undesirable when people can guess nationality based on one's foreign accent;

- sounding native makes one a more confident speaker;

- when one sounds native, others perceive him/her as more intelligent/well-educated.

Selected comments are as follows:

(10) As an interpreter I want to be fluent and sound like a native speaker. Nativelike pronunciation is regarded as indicative of high status, prestige and professionalism

(11) The accent is an important part of learning language, in my opinion as important as vocabulary and grammar.

(12) I try to be as native-like as possible in order to be taken seriously.

(13) Because, I would like to be treated as someone intelligent. Also, I don't want to be associated with Polish when I'm abroad.

As a counter perspective, the following is a quotation from one of the few respondents who claim not to attach importance to achieving a native-speaker accent:

(14) As long as native and non-native speakers of English can understand me without any problems it is enough for me. What is more, in contacts with foreigners whose L1 is not English I discovered that they have serious problems with understanding RP. It is quite ironic - a lot of people whom I talked to aspire to sound British but most of them have real difficulties in comprehending utterances spoken in British accent. Therefore I think that especially in contacting non-native speakers it is better to choose one's 'natural' accent if I may say so. By 'natural' I mean not pretending to be British, American, etc. However, I believe it's very very very important to pay attention to phonetics and stick to the way words should be pronounced so that the speaker can be understood. 
A different comment, somehow reflective in tone, is as follows:

(15) Because on the one hand I want to be treated as serious person, but on the other, I think that non-native elements in accent are quite beautiful, unique and intriguing. However, the majority of people look down on it and criticise.

Questions 14 and 15: My university teachers put too much focus on native-speaker pronunciation. Why do you think so? Please, comment.

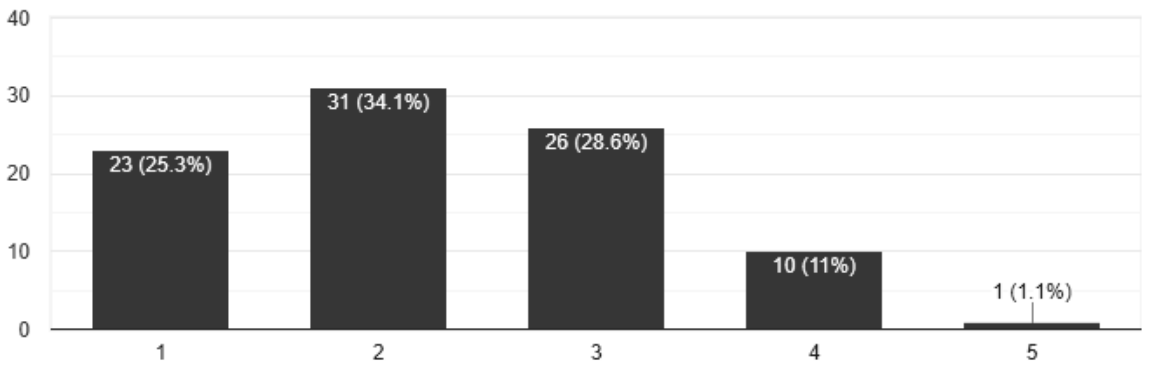

Figure 11

US respondents' opinion of whether their teachers put too much focus on native-speaker pronunciation (5 - strongly agree, 1-strongly disagree)

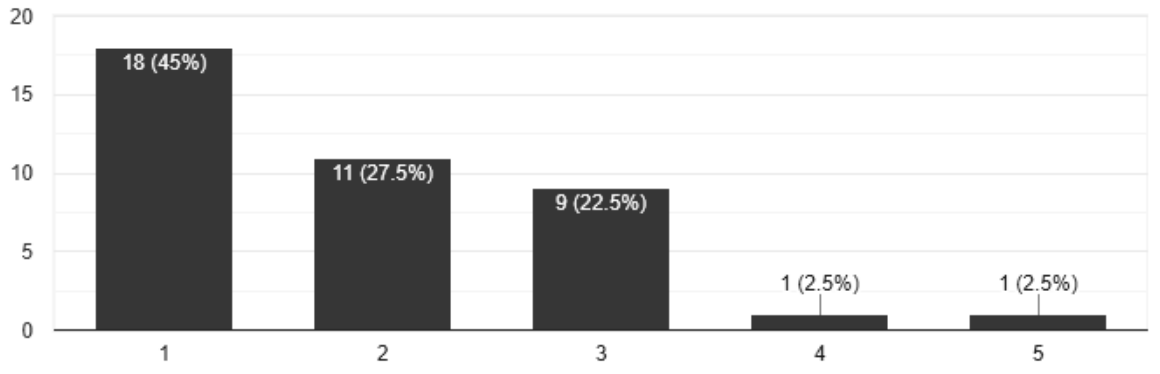

Figure 12

UW respondents' opinion of whether their teachers put too much focus on native-speaker pronunciation

(5 - strongly agree, 1-strongly disagree) 
The answers to questions 14 and 15 reveal that the students expect from their university teachers not less but actually more focus on native-speaker pronunciation. A prevailing opinion is that university teachers put too little focus on instilling native-like pronunciation in students. The respondents from both universities complained that teachers do not correct their pronunciation or that correction takes place only during phonetics classes in the first year of their studies, but is otherwise neglected:

(16) This is actually a problem because teachers don't put much attention to teaching proper pronunciation.

(17) I very rarely meet with comments concerning my accent. I know I should improve, but nobody seemed willing to guide me somehow.

(18) University teachers, apart from phonetics classes, don't motivate students to try to obtain native-speaker pronunciation.

Criticism was also directed at university teachers for the lack of native-like accent:

(19) [...] when it comes to the accent of most of my teachers there is quite a lot of room for improvement. There were several whose accent is stunning and it was pure pleasure to listen to them [...] but the rest have a clearly acquired accent which in most cases is not perfect. One of the teachers actually speaks worse accent than most of the students which is truly saddening $[\ldots]$

(20) At my faculty we only have one English native speaker and the rest of the teachers don't really have perfect accents themselves.

\section{Discussion and concluding remarks}

For some time now we have been observing the growing role of non-standard English in international communication, which has emerged as one of the major factors influencing interpret- 
ers' work. In Albl-Mikasa's (2013: 3) words, "no other development since the invention and introduction of the technology for simultaneous interpretation after World War II has changed the working conditions and professional self-image of conference interpreters to such a degree". ELF has become so common in international communication that now it constitutes the majority of interpreters' workload. Yet, at the same time, it is interpreting ELF, with its specific accents, unfamiliar phraseology, untypical syntax and mixed registers, that is declared particularly demanding by professional interpreters. The reaction to the changes affecting the interpreting market is the debate on modification of a traditional, native-speaker-oriented interpreting training, so that classroom practice reflects more the working conditions of professional interpreters. Does this global discussion resonate among interpreters-to-be?

As many as $69.2 \%$ of the US respondents and $82.5 \%$ of the UW respondents claim to be familiar with the term "English as a lingua franca" and are able to define it. Yet one must note that the subjects provide no more than surface definitions, which most often come down to pointing out that ELF is a language of global communication. Knowledge of six or more (sub)varieties of the English language is declared by $45.1 \%$ of the US students and $60 \%$ of the UW students. What is telling, however, is that the existence of Outer Circle English is acknowledged by only a handful of respondents and the examples of Expanding Circle English are provided merely by three of them. In general, the responses suggest no systematic knowledge in this area, which, taking into consideration the scope of the ELF phenomenon, should be expected of soon-tobe philology graduates, especially that most of them, as residents of an Expanding Circle country, are likely to work in Expanding Circle contexts, interpreting and translating from Italian English, Russian English, Chinese English etc. The second part of the questionnaire reveals that different (sub)varieties of English are not given equal recognition by the participants. The students associate English varieties with stereotypical fea- 
tures allegedly exhibited by natives representing them. Asked about British English, the respondents produce an avalanche of positive comments, describing this variety as, among others, "sophisticated", "posh", "elegant" and "melodic", but also "magnificent" or "superior". American English receives a more moderate response, described as "simple", "easy", "clear", "common", "friendly" and "casual", with some criticism indicating its inferiority to the UK variety (e.g. "churlish", "simplified", "unrefined" or "sloppy"). In contrast, when asked to describe Polish English, the students provide mostly negative responses, calling it "harsh", "incorrect", "poor" or even "broken" and "nauseating". The students, having such an emotion-laden approach to native-speaker English, might not be motivated to devote time and effort to familiarizing themselves with Expanding and Outer Circle English. They might even openly oppose frequent presence of ELF during classes (both interpreting and practical language classes), since it occurs at the cost of less exposure to Standard British or Standard American.

The respondents' fondness of the native-speaker model finds reflection in their responses concerning their own English accent aspirations. Even though many of them predict to communicate mostly with NNSE (40.7\% US and $52.5 \%$ UW), as much as $81.4 \%$ of the US respondents and $75 \%$ of the UW respondents find it important or very important to master a particular variety of English to the native-speaker pronunciation level. They expect teachers to put emphasis on this aspect of linguistic performance during most of the classes, not only the ones specifically devoted to pronunciation practice $159.4 \%$ US and $72.5 \% \mathrm{UW}$ ). They are critical of the pronunciation of an average Pole and the pronunciation exhibited by some of their teachers, not accepting performance below the level of nativelike. As for their own pronunciation, $40.0 \%$ (US) and $45.2 \%$ (UW) of those who claim to speak English with a non-native accent consider it a problem, while $38.8 \%$ (US) and $38.7 \%$ (UW) of those who claim to speak English with a non-native accent find it unproblematic. They admit that their English 
pronunciation is of sufficient quality to pursue their private or professional activities. Yet, still a large proportion of the students set for themselves an ambitious goal of speaking British or American English "like a native speaker", presumably believing that through acquiring a particular variety they would acquire the features associated with it, e.g. sophistication, intelligence or professionalism. Such a strong emphasis on pronunciation practice by the students might be surprising for interpreting practitioners. Many interpreters admit that given the complexities and technicalities of the source texts they work with, their own accent is actually the least of their worries. Moreover, though native-speaker accent might indeed give the (first) impression of professionalism, it may also occur to be an obstacle in interpreters' work. There is evidence that in international communication contexts native speakers are actually the least intelligible group of English users (Jenkins 2009, Deterding 2010), most likely because of their tendency to use the features of connected speech, e.g. elision, assimilation and weak forms (Jenkins 2009: 204). Having a native-like accent in some ELF communication contexts might prove to be not only confusing, but even harmful. ${ }^{4}$ Since interpreters' work aims at clarity and precision of communication, native-like accent might not be as highly-rated by prospective clients as it is assumed by the students; by some it may be even perceived as an irritating quirk, especially when the native accent is imitated ineptly.

The overall impression emerging from this analysis is that the phenomenon of ELF and the debate surrounding it are not properly communicated to the English philology students. The students' view of the English language appears to be slightly anachronistic and their approach to linguistic education con-

${ }^{4}$ Deterding (2010: 7) provides an example of air-traffic communication, that is one in which international intelligibility is critically important. The official Aviation Radiotelephony Manual recommends that the numeral thousand is pronounced with a / $t /$ rather than $/ \theta /$. In this case, nativespeaker pronunciation is officially not recommended. 
servative, resembling that from a few decades ago when English textbooks presented only the so-called Received Pronunciation as standard pronunciation for the learners to emulate. In the respondents' answers, one can see an underlying assumption that English "belongs" only to NSE, rather than to all those who use it in global communication. Naturally, various voices can be heard in the debate on the role and place of ELF in the present-day world, not all of them in favour of the phenomenon in question. Yet the students' conservatism does not seem to be the result of a thorough contemplation of the problem, but rather insufficient knowledge and uncritical embrace of the stereotypical mass-culture narration that tends to romanticize certain varieties of English while dismissing others.

As a result, the students participating in the study seem not to be particularly interested in any reformulation of the traditional native-speaker-centered model of language education. The results of the study make us wonder whether the introduction of ELF-oriented activities into practical interpreting or language classes would prove effective if not accompanied by solid theoretical underpinning. Students entering a course in interpreting should be equipped with comprehensive and up-to-date knowledge of the specifics of the presentday English-speaking population in the context of the demands of the interpreting market. Otherwise, students might not understand the need to put detailed attention to Outer or Expanding Circle English and might not be motivated to work with non-native English throughout a substantial part of the interpreting course.

The study was carried out at two Polish universities. The results acquired at the University of Silesia and the University of Warsaw turned out to be very similar. The results are also consistent with the findings of the previous study by Szymańska-Tworek (2016) investigating attitudes among English philology students of teacher education programmes at the University of Silesia. Yet we are far from forming conclusions pertaining to all interpreting students in general. Taking into 
consideration the limited scope of this investigation, the results should rather serve the interpreting teachers as the catalyst for reflection about their students' knowledge and attitudes towards ELF, and an invitation to further research in this matter, in other institutional and geographical settings.

\section{References}

Albl-Mikasa, Michaela (2013). "Teaching Globish? The need for an ELF-pedagogy in interpreter training”. International Journal of Interpreter Education 5/1: 3-16. Available at <https://www. cit-asl.org/new/teaching-globish-vol5-1/>. Accessed 20.06.2020.

Albl-Mikasa, Michaela (2014). "English as a lingua franca in international conferences: Current and future developments in interpreting studies". Interpreting and Translation Studies (Korea) 18/3: 17-42.

Albl-Mikasa, Michaela (2017). "ELF and translation/interpreting". In: Jennifer Jenkins, Will Baker, Martin Dewey (eds.). The Routledge Handbook of English as a Lingua Franca. London - New York: Routledge, 369-383.

Albl-Mikasa, Michaela, Livia Bartels, Lorenz Mohler, Bernd Wick (2017). "World Englishes and English as a lingua franca in interpreter training". In: Susanne Hagemann, Julia Neu, Stephan Walter (eds.). Translation/Interpreting Teaching and the Bologna Process. Berlin: Frank \& Timme, 217-240.

Albl-Mikasa, Michaela, Sandra Guggisberg, Fenja Talirz (2017). "(Source) Texting ELF: Native and non-native English speaker discourse production and conference interpreters' preference for the native speaker". In: Lew N. Zybatow, Andy Stauder, Michael Ustaszewski (eds.). Translation Studies and Translation Practice: Proceedings of the 2nd International TRANSLATA Conference, 2014, Part 1. Frankfurt am Main: Peter Lang, 267-275.

Chang, Chia-Chien, Michelle, Min-chia Wu (2014). "Non-native English at international conferences: Perspectives from ChineseEnglish conference interpreters in Taiwan". Interpreting 16/2: 169-190.

Cook, Vivian (1999). "Going beyond the native speaker in language teaching”. TESOL Quarterly 33/2: 185-209. 
Davies, Alan (1991). The Native Speaker in Applied Linguistics. Edinburgh: Edinburgh University Press.

Deterding, David (2010). "ELF-based pronunciation teaching in China”. Chinese Journal of Applied Linguistics 33: 3-15.

Erling, J. Elizabeth, Tom Bartlett (2006). "Making English their own: the use of ELF among students of English at the FUB". Nordic Journal of English Studies 5: 9-40.

Friedrich, Patricia (2012). "ELF, intercultural communication and the strategic aspect of communicative competence". In: Aya Matsuda (ed.). Principles and Practices of Teaching English as an International Language. Bristol, Buffalo and Toronto: Multilingual Matters, 44-54.

Gentile, Paola, Michaela Albl-Mikasa (2017). "“Everybody speaks English nowadays": Conference interpreters' perception of the impact of English as a lingua franca on a changing profession". Cultus: The Journal of Intercultural Mediation and Communication 10/1: 53-66.

Galloway, Nicola (2013). "Global Englishes and English language teaching (ELT): Bridging the gap between theory and practice in a Japanese context". System 41/3: 786-803.

Jenkins, Jennifer (1998). "Rethinking phonology in teacher education". Vienna English Working Papers 7/ 1: 40-46.

Jenkins, Jennifer (2000). The Phonology of English as an International Language. Oxford: Oxford University Press.

Jenkins, Jennifer (2007). English as a Lingua Franca: Attitude and Identity. Oxford: Oxford University Press.

Jenkins, Jennifer (2009). "English as a lingua franca: Interpretations and attitudes". World Englishes 28/2: 200-207.

Jones, Roderick (2014). "Interpreting: A communication profession in a world of non-communication". The AIIC Webzine 65. Available at <https://aiic.net/page/6990/interpreting-a-communicationprofession-in-a-world-of-non-communication/lang/1>. Accessed 20.06.2020.

Kachru, B. Braj (1985). "Standard, codification, and sociolinguistic realism". In: Randolph Quirk, Henry Widdowson (eds.). English in the World. Cambridge: Cambridge University Press, 11-30.

Luo, Wen-Hsing (2018). "A study of Taiwanese university students' English use, learning goals and attitudes toward English as a lingua franca". Studies in Second Language Learning and Teaching 8/4: 775-794. 
Margić, Branka, Dorjana Širola (2009). “(Teaching) English as an international language and native speaker norms: attitudes of Croatian MA and BA students of English". Journal of English as an International Language 5: 129-36.

Matsuda, Aya (2003). "The ownership of English in Japanese secondary schools". World Englishes 22/4: 483-496.

McKay, Sandra Lee (2003). "Toward an appropriate EIL pedagogy: Re-examining common ELT assumptions". International Journal of Applied Linguistics 13/1: 1-22.

Ozturk, Hande, Sevdeger Cecen, Derya Altinmakas (2009). "How do non-native pre-service English language teachers perceive ELF? A qualitative study". English as an International Language Journal 5: 137-146.

Rogerson-Revell, Pamela (2007). "Using English for international business: A European case study". English for Specific Purposes 26/1: 103-120.

Seidlhofer, Barbara (2011). Understanding English as a Lingua Franca. Oxford: Oxford University Press.

Spichtinger, Daniel (2001) "EIL: A global, a European and an Austrian perspective". Vienna English Working Papers 10/1: 48-59.

Szymańska-Tworek, Aleksandra (2016). English as a Lingua Franca: Attitudes of Pre-service Teachers. Unpublished PhD dissertation. Katowice: University of Silesia.

Wach, Aleksandra (2011). "Native-speaker and English as a lingua franca pronunciation norms: English majors' views". Studies in Second Language Learning and Teaching 1/2: 247-266.

\section{Appendix}

\section{Questionnaire}

Have you attended any translation classes so far during your studies?

No

Yes, $30 \mathrm{~h}$

Yes, $60 \mathrm{~h}$

Yes, $90 \mathrm{~h}$

Yes, $120 \mathrm{~h}$ 
Yes, more than $120 \mathrm{~h}$

Other:

Have you attended any interpreting classes so far during your studies?

No

Yes, $30 \mathrm{~h}$

Yes, $60 \mathrm{~h}$

Yes, $90 \mathrm{~h}$

Yes, $120 \mathrm{~h}$

Yes, more than $120 \mathrm{~h}$

Other:

1. Are you familiar with the concept 'English as a lingua franca'?

No

Yes

2. If yes, please give a definition of 'English as a lingua franca'.

3. How many (sub)varieties of English do you know that exist?

1

2

3

4

5

6 or more

4. Please enumerate them.

5. I think I will probably use English more often with:

native speakers

non-native speakers

equally often with native and non-native speakers

I don't know

6. What adjectives would you use to describe British English?

7. What adjectives would you use to describe American English?

8. What adjectives would you use to describe English spoken by Polish people? 
9. Do you speak English with a Polish/non-native accent?

Yes

No

I don't know

10. If you speak English with a Polish/non-native accent, is it a problem for you?

Yes
I don't know

11. Explain why.

12. How important is it for you to sound like a native speaker of English?

\begin{tabular}{|l|l|l|l|l|}
\hline 1 & 2 & 3 & 4 & 5 \\
\hline
\end{tabular}

13. Why? Please comment.

14. My university teachers put too much focus on native-speaker pronunciation.

\begin{tabular}{|l|l|c|c|c|}
\hline 1 & 2 & 3 & 4 & 5 \\
\hline
\end{tabular}

15. Why do you think so? Please comment. 
Aleksandra Szymańska-Tworek ORCID iD: 0000-0002-2436-1551

University of Silesia in Katowice Institute of Linguistics

Gen. Stefana Grota-Roweckiego 5 41-205 Sosnowiec

Poland

aleksandra.szymanska@us.edu.pl

Joanna Sycz-Opoń

ORCID iD: 0000-0002-4606-7062

University of Silesia in Katowice

Institute of Linguistics

Gen. Stefana Grota-Roweckiego 5

41-205 Sosnowiec

Poland

joanna.sycz@us.edu.p1 